\title{
A. Anderssens
}

\section{SCHACHPARTIEEN}

aus den Jahren 1864 und 1865.

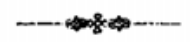

Analgsirl und berausgegeben

von

\section{G. R. Neumann,}

Mitredacteur der neven Berliner Schachzeitung.

7. 7etliit, 1866.

Verlag von Julius Springer

Monbijou-Plats No. 3. 



\section{等}

hochachtungsvoll

der Herausgeber. 
